\title{
Soil fungal community is more sensitive to nitrogen deposition than increased rainfall in a mixed deciduous forest of China
}

\author{
Aihua Zhao ${ }^{1,2}$, Lei $\mathrm{Liu}^{1,3}$, Baodong Chen ${ }^{1,2, *}$, Wei $\mathrm{Fu}^{1,2}$, Wei Xie ${ }^{1,2}$, Tianle $\mathrm{Xu}^{1,4}$, Wei Zhang ${ }^{5}$, Qing $\mathrm{Ye}^{5}$, \\ Haiyan Feng ${ }^{6}$, Shenglei $\mathrm{Fu}^{7}$ \\ 1 State Key Laboratory of Urban and Regional Ecology, Research Center for Eco-Environmental Sciences, Chinese Academy of Sciences, \\ Beijing 100085, China \\ 2 University of Chinese Academy of Sciences, Beijing 100049, China \\ 3 Institute of Ecology, Jiangsu Key Laboratory of Agricultural Meteorology, Nanjing University of Information Science \& Technology, Nanjing \\ 210044, China \\ 4 College of Urban and Environmental Sciences, Peking University, Beijing 100871, China \\ 5 Key Laboratory of Vegetation Restoration and Management of Degraded Ecosystems, South China Botanical Garden, Chinese Academy of \\ Sciences, Guangzhou 510650, China \\ 6 School of Earth Sciences and Resources, China University of Geosciences (Beijing), Beijing 100083, China \\ 7 Laboratory of Geospatial Technology for the Middle and Lower Yellow River Regions, College of Environment and Planning, Henan \\ University, Kaifeng 475004, China
}

\section{ARTICLE INFO}

Article history:

Received August 23, 2019

Revised December 14, 2019

Accepted February 17, 2020

\section{Keywords:}

Climate change

Fungi

Functional group

Saprotrophic fungi

Pathogenic fungi

Mycorrhizal fungi

\section{A B S T R A C T}

Nitrogen $(\mathrm{N})$ deposition and intensified rainfall can strongly affect soil microbial community, but compared with available studies on bacteria, those on soil fungi are quite limited. Here we carried out a field experiment in a mixed deciduous forest of China to study the influences of increased $\mathrm{N}$ deposition and rainfall on soil fungi by using quantitative PCR and high-throughput sequencing method. The results demonstrated that (1) $\mathrm{N}$ addition significantly increased fungal abundance and alpha diversity (richness, Shannon index and Invsimpson index), changed fungal community composition at OTU level, and marginally increased the relative abundance of Ascomycota and Zygomycota, while water addition showed no remarkable effects on fungal abundance, biodiversity and community composition. (2) $\mathrm{N}$ addition significantly increased the richness of saprotrophic fungi and pathogenic fungi, and the relative abundance of saprotrophic fungi, but water addition only slightly increased the abundance of pathogenic fungi. (3) Fungal composition dissimilarity closely correlated with the disparity of soil parameters as a whole. Soil $\mathrm{NH}_{4}{ }^{+}-\mathrm{N}$ exhibited strong positive correlation with the richness of pathogenic fungi and mycorrhizal fungi, while both soil moisture and $\mathrm{NH}_{4}{ }^{+}-\mathrm{N}$ tightly correlated with soil fungal abundance and alpha diversity indices. We concluded that in this $\mathrm{N}$-limited but non-water-limited forest ecosystem, $\mathrm{N}$ deposition posed stronger effects on soil fungi than increased rainfall, partially mediated by changes in soil properties.

(c) Higher Education Press 2020

\footnotetext{
* Corresponding author

E-mail address: bdchen@rcees.ac.cn (B.D. Chen)
} 


\section{Introduction}

Global change is disrupting nearly all ecosystems on earth which would continue in the near future (Ladau et al., 2018). Nitrogen $(\mathrm{N})$ deposition, as an important component of global change, is not an exception. Nitrogen deposition rate has dramatically increased worldwide over the last century (Galloway et al., 2004). As summarized by Zhao et al. (2018), increased $\mathrm{N}$ deposition has brought numerous negative effects on terrestrial ecosystem, such as decline in biodiversity and productivity, soil acidification, nutrient imbalance and forest degradation. Concurrent with increased $\mathrm{N}$ deposition, the average rainfall, in many mid-latitude regions, would also gradually increase (IPCC 2013). Increased rainfall has drawn broad attentions as it could alter the composition and structure of plant community and aboveground net primary productivity (ANPP), and increase the loss of soil nutrient through leaching (Zhao et al., 2018). Intensified rainfall could also stimulate soil respiration and greenhouse gases emissions, such as $\mathrm{CO}_{2}$ and $\mathrm{N}_{2} \mathrm{O}$ (Brown et al., 2012; Liu et al., 2016; Ni et al., 2019).

Fungi are ubiquitous in all kinds of ecosystems and play crucial roles in ecosystem functioning, such as decomposition and nutrient cycling (Thorn, 1997; Aguilar-Trigueros et al., 2015). According to their trophic modes, fungi can be classified into three groups: (1) saprophytic fungi obtaining nutrients by breaking down necromass or organic matter; (2) pathogenic fungi harnessing living hosts (including phagotrophs); and (3) mycorrhizal fungi (symbiotic fungi) receiving carbohydrates by exchanging resources with host plants (Nguyen et al., 2016). Saprophytic fungi decompose plant litter, transfer litter-derived $\mathrm{C}$ into soil, translocate soil-derived inorganic $\mathrm{N}$ up into the litter layer and assimilate carbon and other nutrients into fungal biomass, play a vital role in $\mathrm{C}$ and $\mathrm{N}$ cycle (Frey et al., 2003). While, pathogenic fungi, can infect certain plants, animals or other fungi (Gilbert and Webb, 2007; Dagenais and Keller, 2009; Looby and Treseder, 2018), causing diseases, and changing their community composition and structure. Mycorrhizal fungi, can form mutualistic symbiosis with most terrestrial plants and confer lots of benefits, such as improving plant uptake of mineral nutrients and water to exchange for carbohydrates (Smith and Read, 2008) and protecting host plant from biotic (Affokpon et al., 2011) and abiotic stresses (Chen et al., 2018; Wu et al., 2018).

In view of the important functions of soil fungi, many studies examined the impacts of $\mathrm{N}$ deposition on soil fungi. In general, simulated $\mathrm{N}$ deposition by $\mathrm{N}$ addition can increase soil fungal abundance (Zhou et al., 2016; Wang et al., 2018a) but decrease fungal alpha diversity, while fungal compositions at phylum level seemed to be resistant to $\mathrm{N}$ addition (Wang et al., $2018 b)$. However, the effects of $\mathrm{N}$ deposition on soil fungi could be highly variable and inconsistent, as influenced by ecosystem types, soil conditions, $\mathrm{N}$ addition rate, duration of treatment, and other factors that can directly or indirectly alter the resource quantity and quality for soil fungi (Keiblinger et al., 2010; Li et al., 2018). Similarly, the effects of increased rainfall and $\mathrm{N}$-water interaction on fungal community are also largely elusive. Results of limited studies are highly variable: rainfall increment could have positive (McGuire et al., 2012), negative (Hawkes et al., 2011) or no effects (She et al., 2018) on fungal alpha diversity. For the impacts of elevated rainfall on soil fungal community composition, different studies also failed to reach a general conclusion (Hawkes et al., 2011; She et al., 2018). Moreover, increased rainfall could weaken the effects of $\mathrm{N}$ deposition on fungal alpha diversity (Zhang et al., 2018a), but no significant interactive impacts of $\mathrm{N}$ and water on fungal alpha diversity and community composition were detected in She et al. (2018).

In addition to general fungal biodiversity and community composition, the response of different fungal groups following $\mathrm{N}$ input has attracted more and more attentions. Latest research indicated that the relative abundance of Ascomycota responded positively to $\mathrm{N}$ addition (Zhou et al., 2016; She et al., 2018) and the proportion of saprotrophic fungi could also increase following $\mathrm{N}$ application due to increased resource (such as $\mathrm{N}$ and $\mathrm{C}$ ) availability favoring fast-growing, copiotrophic fungi (Morrison et al., 2016). In addition, it was reported that application of inorganic fertilizer ( $N, P$ and $K$ ) increased the relative abundance of potentially pathogenic fungi (Hu et al., 2017; Wang et al., 2018a). By contrast, the richness and abundance of mycorrhizal fungi would decrease following high dose $\mathrm{N}$ input owing to the decline of dependence of plant on them under increased $\mathrm{N}$ availability, soil acidification and changes in aboveground plant community (Rousk et al., 2010; Huang et al., 2014; Chen et al., 2017; Barnes et al., 2018). On the other hand, saprophytic fungi can be affected by soil temperature and humidity conditions (Meier et al., 2010; Looby and Treseder, 2018), and are likely to benefit from enhanced rainfall (Barnes et al., 2018), which may be mediated by microclimate, soil moisture and other processes. Similarly, increased moisture caused by elevated rainfall can promote the growth, proliferating and dispersal of existing pathogenic fungi (Woods et al., 2005; La Porta et al., 2008) and the emergence of new pathogenic fungi favoring wet conditions.

Compared to scanty studies on the effects of changes in precipitation patterns on fungal community in grassland ecosystems with water deficiency, only few reports are from well-watered forest ecosystems. Forest ecosystems normally have higher biodiversity than arid or semi-arid grassland ecosystems, and high biodiversity is likely linked with high stability of ecosystem processes in response to environmental changes (Loreau and de Mazancourt, 2013); on the other hand, in well-watered ecosystems, the effects of increased water may be different from arid or semi-arid ecosystems in which water is one of the main limiting factors for productivity. Therefore, soil fungi in forest ecosystems may have different feedback to increased precipitation, which still need solid evidences. The last but not of least importance is that $\mathrm{N}$ or water application in most studies on forest ecosystems were 
conducted in the understory, which may not faithfully reflect natural conditions. As well known, many $\mathrm{N}$-related ecological processes occurred in canopy, such as $\mathrm{N}$ uptake, volatilization and transformation (Zhang et al., 2015). On the other hand, rainfall can be partitioned into interception, throughfall and stemflow by forest canopy. Throughfall is defined as the rainfall that drip from canopy surfaces or through gaps, while stemflow is the rainfall that drains from outlying crown components and then is converged to the stem (Rosier et al., 2015a). As summarized by Rosier et al. (2015a), throughfall and stemflow are differentially enriched with diverse substances, including micro- and macronutrients, heavy metals and dissolved or particulate organic matter, some of which are common allelochemicals. Therefore, canopy rainfall partitioning could play an important role in structuring soil microbial community through altering the amount of throughfall and soil characteristics, such as soil moisture, soil nutrients and concentration of allelochemicals (Rosier et al., 2015a, 2015b, 2016). Additionally, canopy rainfall partitioning may also change microbial density through influencing fine root distribution and the supplies of water and nutrients along root pathways (Rosier et al., 2015a).

Due to limited knowledge of the interactive effects of $N$ deposition and rainfall regime on soil fungal community in forest ecosystem, we carried out a field trial to study the impacts of canopy addition of $\mathrm{N}$ and water on soil fungal community in a mixed forest of China. Our hypotheses are as follows: (1) Nitrogen deposition could significantly increase fungal abundance but decrease fungal alpha diversity and alter fungal community composition, while water addition would have no significant effects in the non-water-limiting forest ecosystem. (2) Nitrogen or water addition would have positive effects on the abundance and richness of pathogenic and saprotrophic fungi but negative effects on that of mycorrhizal fungi. (3) Impacts of $\mathrm{N}$ and water addition on soil fungal community would be partially mediated by changes in soil properties.

\section{Materials and methods}

\subsection{Study site}

The experiment was carried out in Jigongshan (JGS) National Nature Reserve $\left(31^{\circ} 46^{\prime}-31^{\circ} 52^{\prime} \mathrm{N}, 114^{\circ} 01^{\prime}-114^{\circ} 06^{\prime} \mathrm{E}\right)$, Xinyang, Henan, China. The soil type is Ferri-Udic Argosols (yellow-brown sandy-loam soil) and the soil $\mathrm{pH}$ value is 5.06.0. Based on meteorological data over the past 60 years (1951-2011), the local mean annual temperature (MAT) is $15.2^{\circ} \mathrm{C}$ and the mean annual precipitation (MAP) is $1119 \mathrm{~mm}$, of which $80 \%$ occurs in April-October (Zhang et al., 2015). The background $\mathrm{N}$ deposition rate in precipitation is $19.6 \mathrm{~kg} \mathrm{~N}$ ha ${ }^{-1} \mathrm{yr}^{-1}$, in which the $\mathrm{NH}_{4}{ }^{+} / \mathrm{NO}_{3}{ }^{-}$ratio is close to 1 (Zhang et al., 2015). The dominant tree species at the JGS area were Quercus acutissima Carruth., Quercus variabilis BI., and Liquidambar formosana Hance, and more information of JGS Reserve were described by Zhang et al. (2015).

\subsection{Experimental design}

This experiment was a completely randomized two-factor block design with canopy addition of $\mathrm{N}$ and water since 2013. There were four blocks in total, and each block included four circular plots with $17 \mathrm{~m}$ in radius. Within each block, each plot was randomly assigned with one of the four treatments: control (CK, ambient environment); canopy addition of $\mathrm{N}(\mathrm{CN})$ at $25 \mathrm{~kg} \mathrm{ha}^{-1} \mathrm{yr}^{-1}$; canopy addition of water (CW) equal to total amount of $336 \mathrm{~mm}$ precipitation (30\% of MAP) every year; and canopy addition of both $\mathrm{N}$ and water (CNW). The interference among treatments was minimized as there was a buffer zone between any two plots (at least $20 \mathrm{~m}$ ). A polyvinylchloride (PVC) board (1 $\mathrm{m}$ in depth) was inserted in the middle of the buffer zone.

Nitrogen was applied as $\mathrm{NH}_{4} \mathrm{NO}_{3}$ solution with a concentration of $3.85 \mathrm{mmol} \mathrm{L}^{-1}$, both the solvent and water were collected from the local lake. Nitrogen and water were added during the growing season from April to October, and $\mathrm{N}$ was applied once a month (totally seven times per year), while water was added once a week (12 mm per week) for minimizing surface runoff. Nitrogen solution or water were added at almost $5 \mathrm{~m}$ above the forest canopy using canopy spraying system built in the center of each plot (Fig. 1). The composition, working principle and efficiency of the system were fully described by Zhang et al. (2015) and Shi et al. (2018).

\subsection{Soil sampling and measurement of soil properties}

Soil samples were collected in late November of year 2017 after 5-year experimental treatment. Ten soil cores $(3 \mathrm{~cm}$ diameter, $10 \mathrm{~cm}$ depth) per plot were taken and mixed into one soil sample. The fresh soil samples were transported to laboratory on ice bag, passed through a 2-mm sieve, and divided into 2 subsamples. One was for the DNA extraction, the other for analysis of soil parameters.

Soil available phosphorus (AP) was determined by the Mo$\mathrm{Sb}$ anti-spectrophotometry method after extraction with $0.5 \mathrm{M}$ $\mathrm{NaHCO}_{3}$ (Olsen et al., 1954). Soil pH was measured using PB-10 pH-meter (Sartorius, Göttingen, Germany) in a 1:2.5 (w/v) aqueous solution. Soil organic matter (SOM) was measured according to Walkley (1947). Total carbon (TC) and total $\mathrm{N}$ (TN) were determined using an element analyzer (Vario EL, Elementar, Germany) and C/N ratio was calculated based on TC and TN. Soil moisture content was measured gravimetrically by oven drying the fresh soil samples to constant weight at $105^{\circ} \mathrm{C}$. Soil available $\mathrm{N}$ (AN) including $\mathrm{NH}_{4}{ }^{+}-\mathrm{N}$ and $\mathrm{NO}_{3}{ }^{-}-\mathrm{N}$ were extracted with $2 \mathrm{~mol} \mathrm{~L}^{-1} \mathrm{KCl}$ with a soil/water ratio of $1: 5$ and measured using a continuous flow analyzer (SAN + + , Skakar, Breda, Holland). Soil N/P ratio was calculated based on AN and AP.

\subsection{Soil DNA extraction and real-time quantitative PCR (qPCR)}

Soil DNA was extracted from $0.25 \mathrm{~g}$ freeze-dried soil sample 


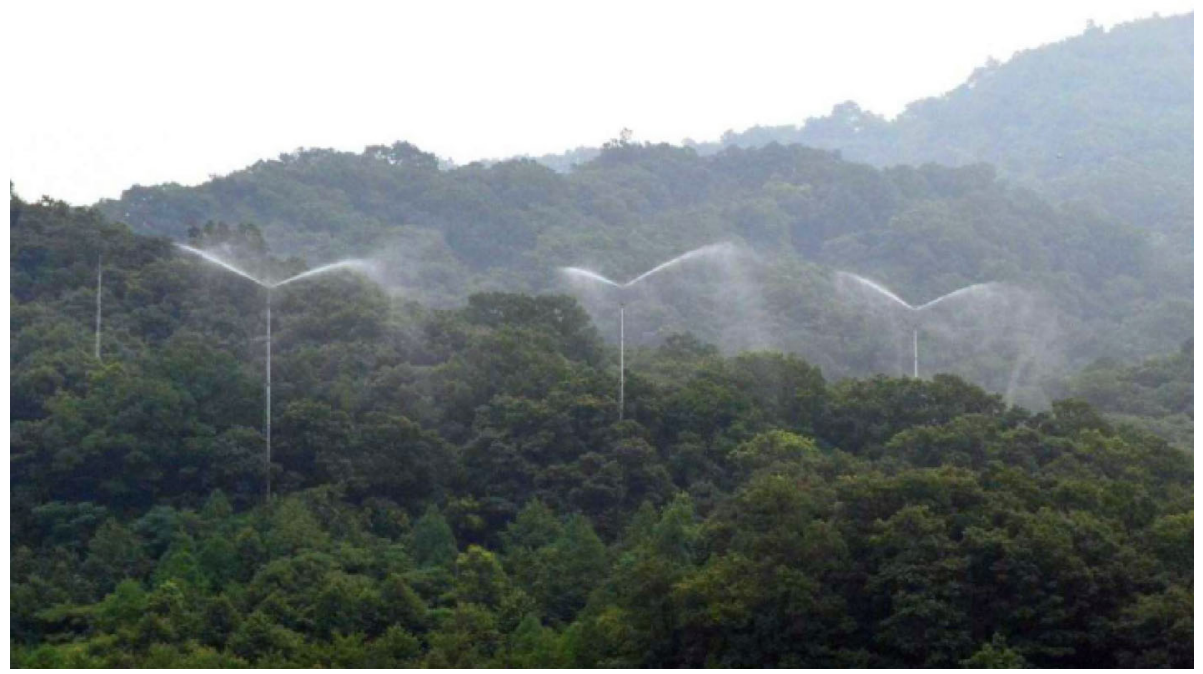

Fig. 1 Photography of the canopy spraying system.

using Power-Soil ${ }^{\circledR}$ DNA Isolation Kit (MOBIO Laboratories Inc., Carlsbad, CA USA) according to the manufacturer's instructions. The quantity and quality of DNA samples were measured with NanoDrop 1000 spectrophotometer (Thermo Scientific, Waltham, MA USA).

The fungal $18 \mathrm{~S}$ gene copy numbers of all samples were determined by CFX Manager (Bio-Rad Laboratories Inc., Hercules, CA USA) with the forward primer 5'-CGGCTACCACATCCAAGGAA-3' and the reverse primer 5'-GCTGGAATTACC GCGGCT-3'. The standard curve was generated from a clone with the $18 \mathrm{~S}$ gene correct insert in 10-fold serial dilutions. The $10 \mu \mathrm{L}$ PCR reaction mixture contained $5.0 \mu \mathrm{L}$ $2 \times$ SG Green qPCR Mix (Kapa Biosystems, Wilmington, MA USA), $0.2 \mu \mathrm{L}(20 \mu \mathrm{M})$ of each primer, $3.6 \mu \mathrm{L} \mathrm{ddH}_{2} \mathrm{O}$ and $1.0 \mu \mathrm{L}$ DNA template. The reaction conditions comprised an initial denaturation at $95^{\circ} \mathrm{C}$ for $3 \mathrm{~min}$, followed by 40 cycles of $95^{\circ} \mathrm{C}$ for $10 \mathrm{~s}, 62.5^{\circ} \mathrm{C}$ for $20 \mathrm{~s}$, and $72^{\circ} \mathrm{C}$ for $10 \mathrm{~s}$. Four technical replicates were performed for each sample. The fungal $18 \mathrm{~S}$ gene copy number was calculated according to a regression equation to convert the cycle threshold (Ct value) to the known number of gene copies in standards.

\subsection{Illumina HiSeq sequencing and bioinformatics}

We conducted PCR amplification with tagged primer pair ITS1F/ITS2 (targeting at ITS1 region for Illumina sequencing) (Rajala et al., 2012). The PCR reaction system was $50 \mu \mathrm{L}$, which contained $5.0 \mu \mathrm{L} 10 \times$ Ex Taq Buffer $\left(\mathrm{Mg}^{+}\right.$plus $)$, $4.0 \mu \mathrm{L}$ dNTP mixture, $0.5 \mu \mathrm{L}$ Ex Taq $\left(5 \mathrm{U} \mu \mathrm{L}^{-1}\right.$ ) (TaKaRa, Dalian, China), $1.5 \mu \mathrm{L}(10 \mu \mathrm{M})$ of each primer, $36.5 \mu \mathrm{L}$ sterilized water and $1.0 \mu \mathrm{L}$ DNA template. The PCR amplification program were as follows: $98^{\circ} \mathrm{C}$ for $3 \mathrm{~min} ; 30$ cycles at $98^{\circ} \mathrm{C}$ for $10 \mathrm{~s}, 54^{\circ} \mathrm{C}$ for $30 \mathrm{~s}, 72^{\circ} \mathrm{C}$ for $30 \mathrm{~s}$; followed by $72^{\circ} \mathrm{C}$ for $10 \mathrm{~min}$. Each sample was amplified in duplicates (technical repetition to minimize the stochastic error) and then mixed into one representing corresponding sample.
PCR products were separated through a $1.5 \%$ agarose (Biowest, Nuaillé, France) gel in $1 \times T A E$, bands were excised, and purified with GeneJET Gel Extraction Kit (Thermo Fisher Scientific, Waltham, MA USA). The amount of DNA in the purified PCR products were measured using a Qubit 3.0 Fluorometer (Thermo Fisher Scientific, Waltham, MA USA) and mixed at equimolar concentrations, then used to construct DNA library using NEBNext Ultra DNA Library Prep Kit for Illumina (New England Biolabs, Ipswich, MA USA) following the standard workflow. Qualified library was sequenced on the Illumina HiSeq2500 (PE250) platform at Beijing Fixgene Technology Co., Ltd (Beijing, China).

The initial quality filtering and assembling of paired-end reads were performed by Beijing Fixgene Technology Co., Ltd. Quality control was achieved by NGSTQCToolkit v 2.3.3. Main procedures were as follows: (1) Remove the low-quality reads $(Q$ value $<20)$; (2) Delete reads containing adapters (short reads). Paired-end reads were assembled by FLASH v.2.2.0 (Magoč and Salzberg, 2011). Raw sequences data have been submitted to Sequence Read Archive database of NCBI under the BioProject ID PRJNA561473. Sequences with maxhomop $>8$, maxambig $>0$ or shorter than 200 bp were removed. The detection and deletion of chimeras and OTU clustering at a $97 \%$ similarity cutoff were achieved in Usearch v.9.0.2132_i86linux32 (Edgar, 2010). OTUs $<5$ sequences were discarded. Taxonomic assignment was performed by blasting the representative sequence of each OTU against UNITE database v.7.2 (release date 12.01.2017) (Nilsson et al., 2019) using the BLASTN search algorithm (Altschul et al., 1997). Only OTUs with representative sequences belong to fungi with similarity $\geqslant 90 \%$, e value $<\mathrm{e}^{-50}$, alignment length $>150$ bp and singleton with identity $>98 \%$ were used in subsequent analysis.

We classified fungal OTUs into functional groups according to FUNGuild database (Nguyen et al., 2016). We only focused on taxa with confidence levels "highly probable" or "probable" 
and unique trophic guilds which belong to saprotrophic fungi, pathogenic fungi or mycorrhizal fungi. Saprotrophic fungi included undefined saprotroph, wood saprotroph, soil saprotroph, plant saprotroph, litter saprotroph and dung saprotroph; pathogenic fungi referred to plant pathogen, animal pathogen and fungal parasite; mycorrhizal fungi consisted of ectomycorrhizal (EcM) fungi and arbuscular mycorrhizal (AM) fungi.

\subsection{Statistical analysis}

All statistical analyses were performed in $\mathrm{R}(\mathrm{R}$ Development Core Team). To avoid bias caused by different sequencing depth, samples were resampled to the minimum 27061 sequences per sample, and then 'Hellinger' transformed to calculate fungal alpha diversity indices (species richness, Shannon and InvSimpson). The alpha diversity indices were calculated using the function 'diversity' in R package 'vegan' (Oksanen et al., 2013). To analyze the effects of $\mathrm{N}$ and water addition and their interactions on soil properties, fungal abundance and alpha diversity indices, two-way analysis of variance (ANOVA) was performed, followed by Duncan's multiple range test. The significant difference was accepted at $P<0.05$. To assess the impacts of $\mathrm{N}$, water addition and their interactions on fungal community composition, two-way permutational multivariate analysis of variance (PERMANOVA) (Anderson, 2010) were performed with the "BrayCurtis dissimilarity" using the function 'adonis2' in R package 'vegan' (Oksanen et al., 2013) with 9999 permutations. To analyze the relationship between soil parameters (available phosphorus (AP), pH, soil organic matter (SOM), total carbon (TC), total $\mathrm{N}(\mathrm{TN})$, soil moisture, $\mathrm{NH}_{4}{ }^{+}-\mathrm{N}, \mathrm{NO}_{3}{ }^{-} \mathrm{N}$, available $\mathrm{N}$ (AN), $\mathrm{C} / \mathrm{N}$ ratio, N/P ratio) and fungal abundance, alpha diversity indices or the richness of each functional group, we performed Pearson correlation analysis. Mantel test was conducted to analyze the disparity of soil factors and the dissimilarity of fungal community composition. The disparity of soil factors was evaluated by 'Euclidean distance' and the dissimilarity of fungal community composition was determined by 'Bray-Curtis distance', both were implemented by 'vegdist' function in R package 'vegan' (Oksanen et al., 2013). To identify the contribution of each soil parameters, we conducted variation partition analysis using 'varpart' function in $\mathrm{R}$ package 'vegan' (Oksanen et al., 2013).

In all the analyses involving fungal alpha diversity indices, the abundance and richness of each functional group, and soil parameters, Dixon's $Q$ test was performed at $95 \%$ confidence level in order to discover outliers (Dean and Dixon, 1951), and some data, including $\mathrm{NO}_{3}{ }^{-} \mathrm{N}, \mathrm{AN}$ and $\mathrm{N} / \mathrm{P}$, were sqrt transformed to satisfy the assumption of normality.

\section{Results}

3.1 Changes of soil parameters after canopy addition of $\mathrm{N}$ and water

For all soil parameters, only $\mathrm{pH}$ value was significantly decreased by canopy $\mathrm{N}$ addition, while no any significant changes were induced by water addition (Table 1).

\subsection{Effects of canopy addition of $\mathrm{N}$ and water on fungal} abundance

Nitrogen input significantly increased fungal abundance, while, water addition had no significant influence; moreover, there was a significant $\mathrm{N}$-water interactions: $\mathrm{N}$ addition increased fungal abundance in case of no water addition only, but no significant effects with water addition (Table 2).

\subsection{The overall output of DNA-sequencing}

After filtering out chimeras, 2199448 sequences were kept and clustered into 3238 OTUs; After discarding OTUs with less than 5 sequences, there were 2969 OTUs (2198412 sequences). Following blasting against UNITE database,

Table 1 Effects of canopy addition of nitrogen and water on soil parameters.

\begin{tabular}{|c|c|c|c|c|c|c|c|}
\hline & \multicolumn{4}{|c|}{ Treatments } & \multicolumn{3}{|c|}{ Significance } \\
\hline & CK & $\mathrm{CN}$ & $\mathrm{CW}$ & CNW & $\mathrm{N}(\mathrm{F}, P)$ & $\mathrm{W}(\mathrm{F}, P)$ & $\mathrm{N} \times \mathrm{W}(\mathrm{F}, P)$ \\
\hline $\mathrm{AP}(\mathrm{mg} / \mathrm{kg})$ & $22.86 \pm 6.35(a)$ & $18.24 \pm 3.90(a)$ & $25.95 \pm 1.40(a)$ & $35.74 \pm 4.88(a)$ & $0.530,0.485$ & $1.258,0.291$ & $0.146,0.711$ \\
\hline $\mathrm{pH}$ & $4.49 \pm 0.07(a)$ & $4.29 \pm 0.04(b)$ & $4.57 \pm 0.07(a)$ & $4.27 \pm 0.04(b)$ & $16.664, \mathbf{0 . 0 0 3}$ & $0.067,0.802$ & $0.952,0.355$ \\
\hline SOM $(g / k g)$ & $33.16 \pm 3.64(a)$ & $35.55 \pm 2.76(a)$ & $33.78 \pm 3.86(a)$ & $34.43 \pm 1.31(a)$ & $0.000,0.989$ & $0.364,0.561$ & $0.657,0.439$ \\
\hline $\mathrm{TC}(\%)$ & $3.33 \pm 0.62(a)$ & $3.28 \pm 0.31(\mathrm{a})$ & $2.96 \pm 0.28(a)$ & $3.25 \pm 0.17(a)$ & $0.029,0.868$ & $1.257,0.288$ & $0.001,0.971$ \\
\hline TN (\%) & $0.19 \pm 0.01(a b)$ & $0.18 \pm 0.00(b)$ & $0.20 \pm 0.01(a)$ & $0.18 \pm 0.00(a b)$ & $3.017,0.116$ & $2.019,0.189$ & $0.623,0.450$ \\
\hline $\mathrm{C} / \mathrm{N}$ & $17.50 \pm 2.53(\mathrm{a})$ & $18.50 \pm 1.24(a)$ & $14.47 \pm 1.01(a)$ & $18.29 \pm 0.84(a)$ & $1.021,0.339$ & $4.372,0.066$ & $0.058,0.816$ \\
\hline Moisture & $18.14 \pm 0.83(a)$ & $20.70 \pm 0.73(a)$ & $19.66 \pm 1.19(a)$ & $23.37 \pm 0.93(a)$ & $4.343,0.067$ & $0.835,0.385$ & $0.641,0.444$ \\
\hline $\mathrm{NH}_{4}{ }^{+}-\mathrm{N}(\mathrm{mg} / \mathrm{kg})$ & $3.63 \pm 0.56(a)$ & $4.54 \pm 0.47(a)$ & $3.89 \pm 0.44(a)$ & $3.89 \pm 0.22(a)$ & $0.583,0.465$ & $0.295,0.600$ & $1.101,0.321$ \\
\hline $\mathrm{NO}_{3}{ }^{-}-\mathrm{N}(\mathrm{mg} / \mathrm{kg})$ & $7.00 \pm 0.86(a)$ & $8.93 \pm 0.86(a)$ & $5.70 \pm 0.53(a)$ & $4.22 \pm 2.91(a)$ & $2.452,0.152$ & $0.227,0.645$ & $0.143,0.714$ \\
\hline AN (mg/kg) & $10.63 \pm 1.13(a)$ & $13.46 \pm 1.12(a)$ & $9.59 \pm 0.92(a)$ & $8.11 \pm 3.01(a)$ & $2.790,0.129$ & $0.128,0.729$ & $0.035,0.856$ \\
\hline N/P ratio & $0.53 \pm 0.09(a)$ & $0.81 \pm 0.11(\mathrm{a})$ & $0.37 \pm 0.02(a)$ & $0.23 \pm 0.29(a)$ & $4.232,0.070$ & $1.715,0.223$ & $0.002,0.968$ \\
\hline
\end{tabular}

$\mathrm{CK}$, control; CN, canopy addition of $\mathrm{N}$; CW, canopy addition of water; CNW, canopy addition of $\mathrm{N}$ and water. Data are presented as means \pm standard error (SE). N, N addition; W, water addition; N $\times$ W, the interaction. Significance of treatment effect was determined by two-way ANOVA. Different letters in brackets next to SE in the same row indicate significant differences $(P<0.05)$ by Duncan's multiple range test. Significant effect $(P<0.05)$ is highlighted in bold. 
Table 2 Impacts of canopy addition of $\mathrm{N}$ and water on fungal abundance and alpha diversity indices.

\begin{tabular}{lcllc}
\hline & 18S gene copies $\left({ }^{*} 10^{8} / \mathrm{g}\right.$ dry soil) & \multicolumn{1}{c}{ Richness } & \multicolumn{1}{c}{ Shannon } & InvSimpson \\
\hline CK & $2.8 \pm 0.3(\mathrm{~b})$ & $617.0 \pm 17.5(\mathrm{~b})$ & $5.8 \pm 0.05(\mathrm{~b})$ & $147.7 \pm 7.1(\mathrm{c})$ \\
CN & $7.9 \pm 0.8(\mathrm{a})$ & $718.0 \pm 19.1(\mathrm{a})$ & $6.0 \pm 0.03(\mathrm{a})$ & $214.9 \pm 7.5(\mathrm{a})$ \\
CW & $5.5 \pm 1.3(\mathrm{ab})$ & $658.0 \pm 21.6(\mathrm{ab})$ & $5.9 \pm 0.05(\mathrm{ab})$ & $173.2 \pm 18.2(\mathrm{bc})$ \\
CNW & $6.2 \pm 0.7(\mathrm{a})$ & $698.3 \pm 15.4(\mathrm{a})$ & $6.0 \pm 0.03(\mathrm{a})$ & $202.0 \pm 7.3(\mathrm{ab})$ \\
Significance & & & \\
$\mathrm{N}(\mathrm{F}, P)$ & $9.338, \mathbf{0 . 0 1 4}$ & $11.316, \mathbf{0 . 0 0 8}$ & $7.475, \mathbf{0 . 0 2 3}$ & $15.196, \mathbf{0 . 0 0 4}$ \\
W (F, P) & $0.246,0.632$ & $0.256,0.625$ & $0.236,0.639$ & $0.261,0.622$ \\
$\mathrm{~N} \times \mathrm{W}(\mathrm{F}, P)$ & $5.596, \mathbf{0 . 0 4 2}$ & $2.093,0.182$ & $1.442,0.260$ & $2.441,0.153$ \\
\hline
\end{tabular}

$\mathrm{CK}$, control; CN, canopy addition of $\mathrm{N}$; CW, canopy addition of water; CNW, canopy addition of $\mathrm{N}$ and water. Data are presented as means \pm standard error (SE). N, N addition; W, water addition; N $\times$ W, the interaction. Significance of treatment effect was determined by two-way ANOVA. Different letters in brackets next to SE in the same column indicate significant differences $(P<0.05)$ by Duncan's multiple range test. Significant effect $(P<0.05)$ is highlighted in bold.

certain OTUs were further excluded with representative sequences: (1) not belong to fungi; (2) e value $>\mathrm{e}^{-50}$; (3) alignment length < $150 \mathrm{bp}$; (4) identity <90\%; (5) singleton with identity $<98 \%$. Screened by strict criteria, a total of 1412 OTUs (1770 382 sequences) were retained.

Among the 1412 fungal OTUs, the unclassified OTUs accounted for $2.3 \%$ and their relative abundance was $7.8 \%$ (138195/1770382). While other OTUs covered 6 phyla, among which, the dominant phyla were Ascomycota, Basidiomycota and Zygomycota (Fig. 2).

3.4 Influences of canopy addition of $\mathrm{N}$ and water on fungal alpha-diversity and community composition

Canopy $\mathrm{N}$ addition significantly increased fungal alpha-

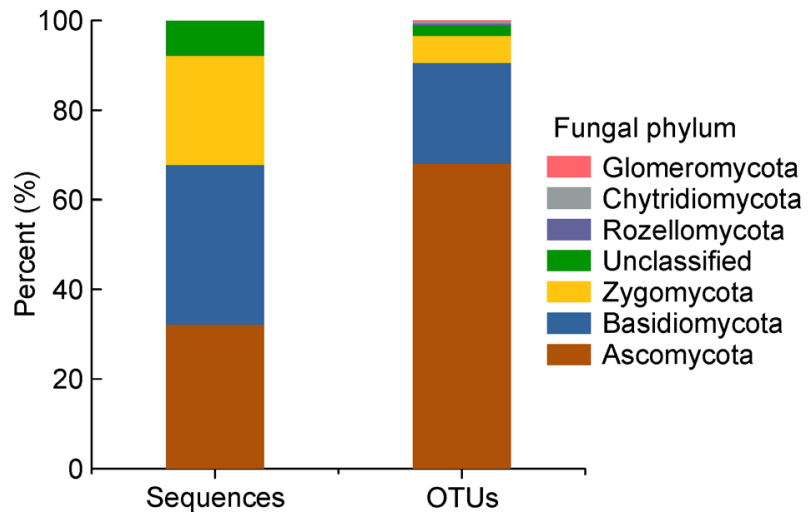

Fig. 2 The proportional distributions of sequences and derived fungal OTUs from all soil samples diversity: richness (number of OTUs), Shannon and InvSimpson index. However, water addition showed no significant effect on any fungal alpha diversity indices. In addition, no significant interactions were detected between $\mathrm{N}$ and water in influencing fungal alpha diversity (Table 2).

For fungal community composition at OTU level, effect of $\mathrm{N}$ addition was significant, but not for water addition; nevertheless, at phylum level, both $\mathrm{N}$ and water showed no significant effects. Meanwhile, there were also no significant interactions of $\mathrm{N}$ and water no matter at OTU level or phylum level (Table 3).

For the relative abundance of the three dominant fungal phyla, $\mathrm{N}$ addition marginally increased the relative abundance of Ascomycota and Zygomycota; in contrast, Basidiomycota relative abundance tended to be decreased by $\mathrm{N}$ addition, but statistically insignificant. However, water addition had no significant influences on the relative abundance of all three fungal phyla (Fig. 3).

3.5 Effects of canopy addition of $\mathrm{N}$ and water on the richness and abundance of different functional groups (saprotrophic fungi, pathogenic fungi and mycorrhizal fungi)

Nitrogen addition significantly increased the richness of saprotrophic fungi and pathogenic fungi (Fig. 4A), moreover, marginal or significant interactions of $\mathrm{N}$ and water were observed in affecting the richness of saprotrophic fungi and pathogenic fungi: water addition weakened the positive effects of $\mathrm{N}$ addition. However, for the richness of mycorrhizal fungi, $\mathrm{N}$, water and their interaction all showed no significant effects (Fig. 4A).

Table 3 Effects of canopy addition of nitrogen and water on fungal community composition.

\begin{tabular}{|c|c|c|c|c|c|}
\hline & \multirow[b]{2}{*}{ df } & \multicolumn{2}{|c|}{ Composition at OTU level } & \multicolumn{2}{|c|}{ Composition at phylum level } \\
\hline & & F-value & $P$-value & F-value & $P$-value \\
\hline $\mathrm{N}$ & 1 & 1.631 & 0.004 & 1.296 & 0.234 \\
\hline W & 1 & 0.921 & 0.630 & 0.351 & 0.980 \\
\hline $\mathrm{N} \times \mathrm{W}$ & 1 & 1.029 & 0.363 & 0.904 & 0.495 \\
\hline
\end{tabular}

F-values and $P$-values are presented, determined by two-way PERMANOVA using 'adonis2' function in R package 'vegan' (Oksanen et al., 2013). $\mathrm{N}$, nitrogen addition; W, water addition; $\mathrm{N} \times \mathrm{W}$, the interaction. Significant effect $(P<0.05)$ is highlighted in bold. 
Simultaneously, $\mathrm{N}$ input showed significant impacts on saprotrophic fungal abundance, while water addition marginally increased pathogenic fungal abundance, but both $\mathrm{N}$ and water did not significantly change mycorrhizal fungal abundance (Fig. 4B). No significant interactions of $\mathrm{N}$ and water were observed (Fig. 4B).

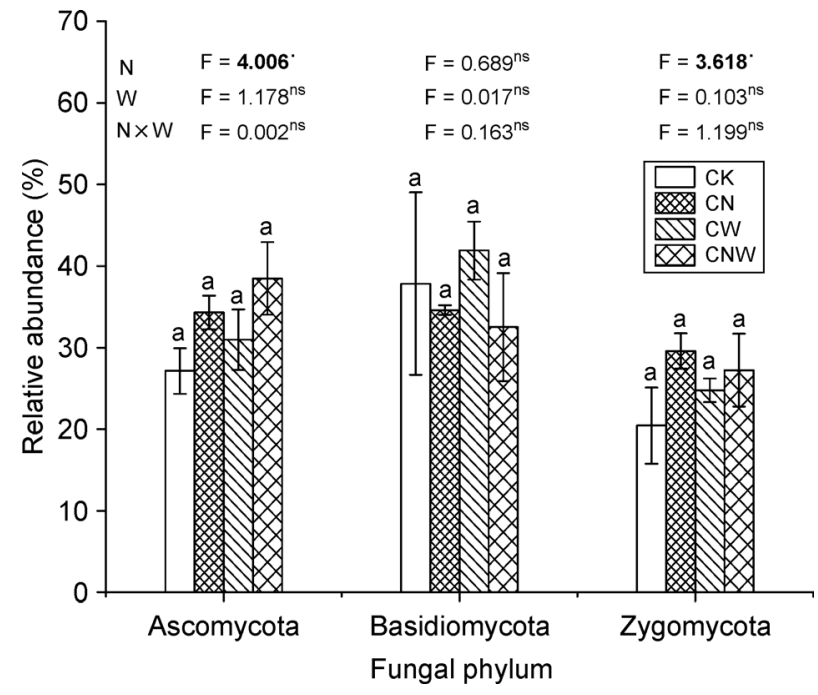

Fig. 3 Impacts of canopy addition of $\mathrm{N}$ and water on the relative abundances of three dominant fungal phyla (Ascomycota, Basidiomycota and Zygomycota). CK, control; CN, canopy application of $\mathrm{N}$; CW, canopy addition of water; CNW, canopy addition of $\mathrm{N}$ and water. $\mathrm{N}, \mathrm{N}$ application; $\mathrm{W}$, water addition; $\mathrm{N} \times$ $W$, the interaction. $F$ values were presented and significance of treatment effect was determined by two-way ANOVA. ${ }^{*} P<0.01$; ${ }^{*} P<0.05 ; \cdot P<0.1$; ns, not significant. Different letters above the columns indicate significant difference between corresponding treatments by Duncan's multiple range test $(P<0.05)$.

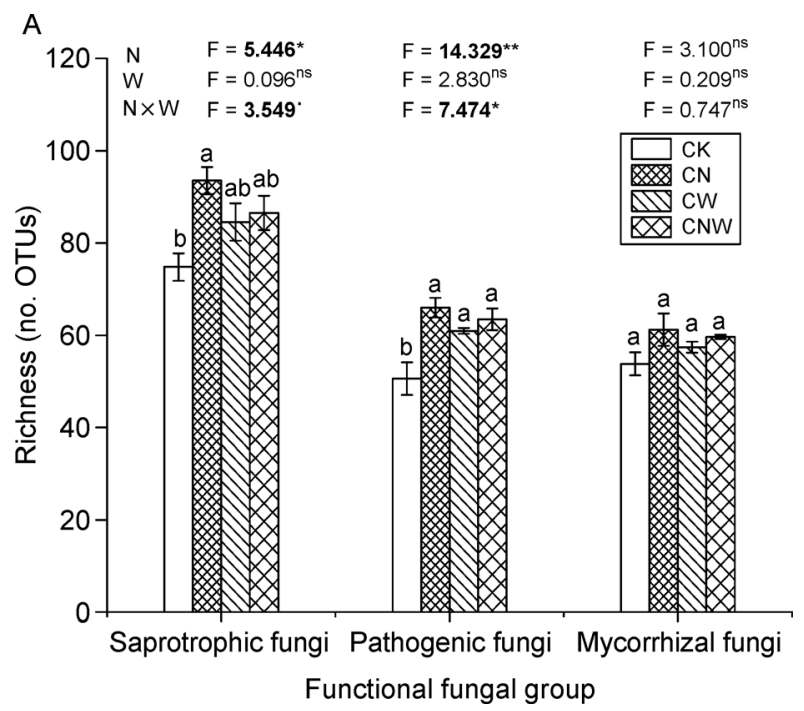

3.6 Relationships between soil factors and fungal abundance, alpha diversity, composition dissimilarity and the richness of each functional fungal group

Pearson correlation analysis demonstrated that soil moisture significantly positively correlated with fungal richness, Shannon index and InvSimpson index. Likewise, soil $\mathrm{NH}_{4}{ }^{+}-\mathrm{N}$ had a significant positive correlation with fungal abundance, InvSimpson index, and marginally positively correlated with fungal richness and Shannon index (Table 4).

In addition, there was a significant positive correlation between fungal community composition dissimilarity and the disparity of all soil factors indicated by Mantel test (Table 5). Eighteen percent the variation in fungal community composition can be explained by changes of soil factors as a whole, among which soil N/P ratio, $\mathrm{AP}$, soil moisture, and $\mathrm{pH}$ value could individually explain $5 \%, 4 \%, 3 \%$, and $1 \%$, respectively (Table 5).

Pearson correlation analysis also demonstrated that soil moisture and the richness of saprotrophic fungi and pathogenic fungi were weakly correlated, meanwhile, the correlation between soil $\mathrm{NH}_{4}{ }^{+}-\mathrm{N}$ content and the richness of saprotrophic fungi, pathogenic fungi and mycorrhizal fungi were marginally significant, significant and highly significant, respectively (Table 6 ). In addition, soil $N: P$ ratio slightly positively correlated with mycorrhizal fungal richness (Table 6).

\section{Discussion}

To understand the effects of multiple climate factors on soil fungal community under natural conditions can help predicting the response of terrestrial ecosystem to future climate

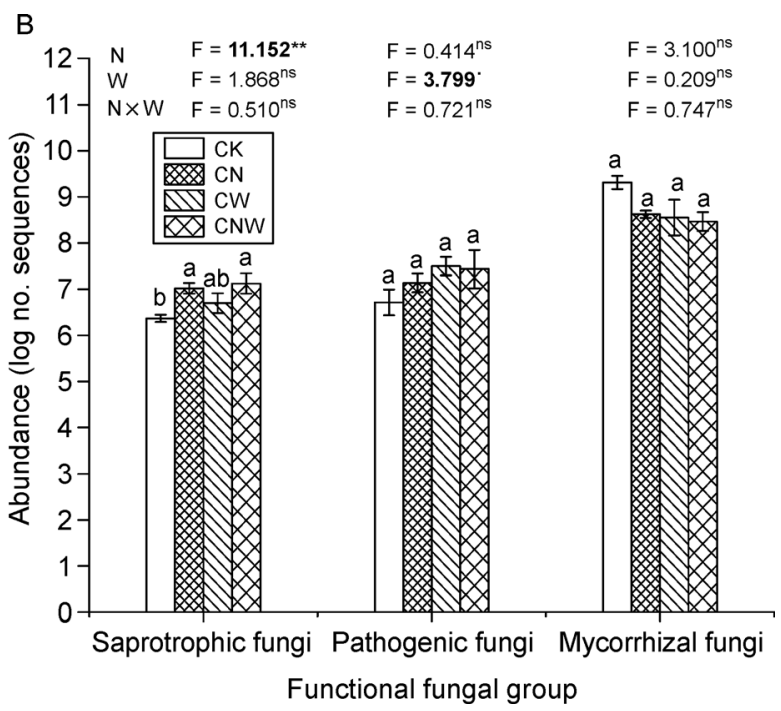

Fig. 4 Effects of canopy addition of $\mathrm{N}$ and water on the richness $(\mathrm{A})$ and abundance $(\mathrm{B})$ of three functional fungal groups. CK, control; $\mathrm{CN}$, canopy application of $\mathrm{N}$; CW, canopy addition of water; $\mathrm{CNW}$, canopy addition of $\mathrm{N}$ and water. $\mathrm{N}, \mathrm{N}$ application; $\mathrm{W}$, water addition; $\mathrm{N} \times \mathrm{W}$, the interaction. $\mathrm{F}$ values were presented and significance of treatment effect was determined by two-way ANOVA. ${ }^{* *} P<0.01 ;{ }^{*} P<0.05 ; \cdot P<0.1$; $\mathrm{ns}$, not significant. Different letters above the columns indicate significant difference between corresponding treatments by Duncan's multiple range test $(P<0.05)$. 
Table 4 Pearson correlation analysis between soil properties and fungal abundance and alpha diversity indices at OTU level.

\begin{tabular}{|c|c|c|c|c|c|c|c|c|c|}
\hline & & $\mathrm{Abu}$ & & & & & & $\operatorname{InvS}$ & \\
\hline & df & $r$ & $P$ & $r$ & $P$ & $r$ & $P$ & $r$ & $P$ \\
\hline AP (mg/kg) & 14 & -0.051 & 0.574 & 0.060 & 0.413 & 0.157 & 0.281 & 0.170 & 0.264 \\
\hline $\mathrm{pH}$ & 14 & -0.182 & 0.750 & -0.185 & 0.754 & -0.097 & 0.639 & -0.293 & 0.865 \\
\hline SOM (g/kg) & 14 & -0.166 & 0.730 & -0.162 & 0.726 & -0.249 & 0.824 & -0.034 & 0.550 \\
\hline TC $(\%)$ & 14 & -0.164 & 0.728 & -0.281 & 0.854 & -0.364 & 0.917 & -0.149 & 0.710 \\
\hline TN (\%) & 14 & -0.320 & 0.887 & -0.297 & 0.868 & -0.324 & 0.889 & -0.215 & 0.789 \\
\hline $\mathrm{C} / \mathrm{N}$ & 14 & 0.005 & 0.493 & -0.150 & 0.710 & -0.247 & 0.822 & -0.021 & 0.530 \\
\hline Moisture & 14 & 0.417 & 0.054 & 0.536 & 0.016 & 0.529 & 0.018 & 0.649 & 0.003 \\
\hline $\mathrm{NH}_{4}{ }^{+}-\mathrm{N}(\mathrm{mg} / \mathrm{kg})$ & 14 & 0.597 & 0.007 & 0.407 & 0.059 & 0.383 & 0.072 & 0.459 & 0.037 \\
\hline $\mathrm{NO}_{3}{ }^{-}-\mathrm{N}(\mathrm{mg} / \mathrm{kg})$ & 14 & 0.172 & 0.263 & 0.217 & 0.209 & 0.222 & 0.205 & 0.288 & 0.139 \\
\hline AN (mg/kg) & 14 & 0.297 & 0.132 & 0.289 & 0.139 & 0.287 & 0.141 & 0.370 & 0.079 \\
\hline N/P ratio & 14 & 0.176 & 0.257 & 0.127 & 0.320 & 0.065 & 0.406 & 0.120 & 0.329 \\
\hline
\end{tabular}

Correlation coefficients and $P$-values are presented, significant effect $(P<0.05)$ is highlighted in bold.

Table 5 Mantel test of fungal community composition dissimilarity with the disparity of soil matrices and variation partition analysis of fungal community composition dissimilarity.

\begin{tabular}{|c|c|c|c|}
\hline & \multicolumn{2}{|c|}{ Mantel test } & \multirow[t]{2}{*}{ Variation partition analysis (explained) } \\
\hline & $r$ & $P$ & \\
\hline All & 0.361 & 0.027 & $18 \%$ \\
\hline $\mathrm{AP}(\mathrm{mg} / \mathrm{kg})$ & 0.168 & 0.149 & $4 \%$ \\
\hline $\mathrm{pH}$ & 0.258 & 0.096 & $1 \%$ \\
\hline SOM (g/kg) & 0.242 & 0.092 & $0 \%$ \\
\hline $\mathrm{TC}(\%)$ & 0.330 & 0.072 & $0 \%$ \\
\hline $\mathrm{TN}(\%)$ & 0.247 & 0.096 & $0 \%$ \\
\hline $\mathrm{C} / \mathrm{N}$ & 0.248 & 0.099 & $0 \%$ \\
\hline Moisture & 0.327 & 0.036 & $3 \%$ \\
\hline $\mathrm{NH}_{4}{ }^{+}-\mathrm{N}(\mathrm{mg} / \mathrm{kg})$ & 0.039 & 0.351 & $0 \%$ \\
\hline $\mathrm{NO}_{3}{ }^{-} \mathrm{N}(\mathrm{mg} / \mathrm{kg})$ & -0.119 & 0.727 & $0 \%$ \\
\hline AN $(\mathrm{mg} / \mathrm{kg})$ & -0.090 & 0.666 & $0 \%$ \\
\hline N/P ratio & 0.032 & 0.302 & $5 \%$ \\
\hline
\end{tabular}

Explained proportions by soil matrices, correlation coefficients and $P$-values are presented, significant effect $(P<0.05)$ is highlighted in bold. The disparity of soil factors was evaluated by 'Euclidean distance' and the dissimilarity of fungal community composition was determined by 'BrayCurtis distance', both were implemented by 'vegdist' function in R package 'vegan' (Oksanen et al., 2013). Variation partition analysis was conducted using 'varpart' function in R package 'vegan' (Oksanen et al., 2013).

scenarios and has far-reaching significance. We studied the influences of 5-year canopy $\mathrm{N}$ and water addition on soil fungal abundance, community composition and different functional groups in a mixed deciduous forest of China. The results showed that fungal abundance and alpha diversity were increased, and community composition (at OTU level) was altered by $\mathrm{N}$ deposition but not by rainfall increment (Tables 2 and 3). Meanwhile, soil fungal community composition, at phylum level (Table 3), was resistant to increased $\mathrm{N}$ and rainfall; but the relative abundance of certain fungal phyla can be marginally altered (Fig. 3). Nitrogen addition significantly increased the richness of pathogenic fungi and saprotrophic fungi and the abundance of saprotrophic fungi (Fig. 4). While, water addition only slightly increased pathogenic fungal abundance (Fig. 4B). Most importantly, counteractive $\mathrm{N}$-water interactions were detected in shaping fungal abundance (Table 2), the richness of pathogenic fungi and saprotrophic fungi (Fig. 4A). As expected, soil parameters played a role in shaping fungal community composition and the richness of each functional group (Tables 4-6).

4.1 Changes in soil properties following canopy $\mathrm{N}$ and water addition

In this study, soil $\mathrm{pH}$ value was most significantly decreased by 5-year canopy $\mathrm{N}$ addition (Table 1), in agreement with many previous reports (Lu et al., 2014; Tian and Niu, 2015). Possible mechanisms are summarized by Zhao et al. (2018): (1) $\mathrm{NH}_{4}{ }^{+}$ions are absorbed by plants leading to $\mathrm{H}^{+}$release; (2) $\mathrm{NH}_{4}{ }^{+}$ions are oxidized to nitrates step by step, producing $\mathrm{H}^{+}$; (3) The loss of base cations and metal cations could abate soil buffer capacity against acidification. In addition, in the meta 
Table 6 Relationships between soil properties and the richness of three functional groups.

\begin{tabular}{|c|c|c|c|c|c|c|c|}
\hline & \multirow[b]{2}{*}{$\mathrm{df}$} & \multicolumn{2}{|c|}{ Saprotrophic fungi } & \multicolumn{2}{|c|}{ Pathogenic fungi } & \multicolumn{2}{|c|}{ Mycorrhizal fungi } \\
\hline & & $r$ & $P$ & r & $P$ & $r$ & $P$ \\
\hline $\mathrm{AP}(\mathrm{mg} / \mathrm{kg})$ & 14 & -0.013 & 0.519 & 0.102 & 0.354 & -0.219 & 0.784 \\
\hline $\mathrm{pH}$ & 14 & -0.051 & 0.574 & -0.200 & 0.771 & -0.351 & 0.900 \\
\hline SOM (g/kg) & 14 & -0.117 & 0.667 & -0.195 & 0.766 & -0.056 & 0.579 \\
\hline TC $(\%)$ & 14 & -0.204 & 0.776 & -0.412 & 0.944 & -0.044 & 0.561 \\
\hline TN (\%) & 14 & -0.118 & 0.669 & -0.348 & 0.907 & -0.218 & 0.782 \\
\hline $\mathrm{C} / \mathrm{N}$ & 14 & -0.154 & 0.715 & -0.256 & 0.831 & 0.132 & 0.319 \\
\hline Moisture & 14 & 0.396 & 0.064 & 0.385 & 0.070 & 0.323 & 0.120 \\
\hline $\mathrm{NH}_{4}{ }^{+}-\mathrm{N}(\mathrm{mg} / \mathrm{kg})$ & 14 & 0.339 & 0.099 & 0.450 & 0.040 & 0.679 & 0.003 \\
\hline $\mathrm{NO}_{3}^{-}-\mathrm{N}(\mathrm{mg} / \mathrm{kg})$ & 14 & 0.270 & 0.156 & -0.018 & 0.527 & 0.102 & 0.359 \\
\hline AN (mg/kg) & 14 & 0.312 & 0.120 & 0.097 & 0.361 & 0.294 & 0.144 \\
\hline N/P ratio & 14 & 0.122 & 0.326 & 0.019 & 0.472 & 0.367 & 0.089 \\
\hline
\end{tabular}

Correlation coefficients and $P$-values are presented, significant effect $(P<0.05)$ is highlighted in bold.

analysis of Tian et al. (2018), the content of soil total $\mathrm{N}$ in temperate forests of China were not significantly increased by $\mathrm{N}$ addition, this paper also confirmed this (Table 1). This could be attributed to low dosage and short duration of $\mathrm{N}$ addition, and increased $\mathrm{N}$ leaching (Tian et al., 2018) and raised emissions of $\mathrm{N}$ oxides (Butterbach-Bahl et al., 1997).

4.2 Impacts of $\mathrm{N}$ and water addition on soil fungal abundance and community composition

In the present study, $\mathrm{N}$ addition significantly increased fungal abundance, confirming our first hypothesis in line with Zhou et al. (2016) and Wang et al. (2018a). The possible mechanisms were: (1) Increased $\mathrm{N}$ availability directly released $\mathrm{N}$ limitation for supporting soil fungal growth; (2) $\mathrm{N}$ input may change plant growth and indirectly alter resource quantity and quality for soil fungi (Keiblinger et al., 2010; Li et al., 2019). Moreover, $\mathrm{N}$ enrichment significantly increased fungal richness (Table 2), in contravention to our first hypothesis, this may be ascribed to the ecosystem type and the $\mathrm{N}$ addition rate, as in the meta analysis of Wang et al. (2018b), the effect size (characterized by the difference between the mean log e-transformed outcome in the treatment group and that in the control group) of fungal Chao1 index (representing fungal richness) was positive (increased) in tundra but negative (decreased) in desert/shrublands under $\mathrm{N}$ addition, but no studies in forests were included; on the other hand, in case of $\mathrm{N}$ addition $<5 \mathrm{~g} \mathrm{~N} \mathrm{~m}^{-2} \mathrm{yr}^{-1}$, the effect of $\mathrm{N}$ input on fungal Chao1 index was positive; when the rate $>5 \mathrm{~g} \mathrm{~N} \mathrm{~m}^{-2} \mathrm{yr}^{-1}$, the effect became negative. The $\mathrm{N}$ addition rate in this study was $25 \mathrm{~kg} \mathrm{ha}^{-1} \mathrm{yr}^{-1}<5 \mathrm{~g} \mathrm{~N} \mathrm{~m}^{-2} \mathrm{yr}^{-1}$, so increased fungal richness by $\mathrm{N}$ addition was understandable. However, the results of a study conducted in forest ecosystems (Entwistle et al., 2013) showed that $\mathrm{N}$ addition had no significant effects on fungal Chao1 richness, this may be partially explained by the experimental duration: the duration of Entwistle et al. (2013) was more than 15 years, while the duration of our experiment was 5 years. When the duration was less than 5 years or more than 10 years the effect could be nonsignificant (Wang et al., 2018b). In addition, InvSimpson index and Shannon index were also increased by $\mathrm{N}$ addition in our study (Table 2). Yet, $\mathrm{N}$ addition significantly decreased fungal Shannon index in forest ecosystems in the synthesized analysis of Wang et al. (2018b), but only 5 papers were incorporated, so the generality of the results may be limited, as they also pointed out that soil conditions, treatment duration, $\mathrm{N}$ addition rate and changes in soil organic carbon under $\mathrm{N}$ addition all influenced the effect size of $\mathrm{N}$ input on microbial Shannon index.

Furthermore, $\mathrm{N}$ input significantly altered fungal community composition at OTU level (Table 3), confirming the results of Morrison et al. (2016), who found that fungal composition was fundamentally changed by more than 20 years of $\mathrm{N}$ addition in a temperate hardwood forest, while contradicted to the work of McHugh et al. (2017) in a semiarid grassland. Besides difference in ecosystem types, experimental duration and $\mathrm{N}$ addition rate probably can explain the different outcomes: the experimental duration in our study was 5 years and in Morrison et al. (2016), it was more than 20 years, while it lasted for only 2 years in McHugh et al. (2017); in addition, $\mathrm{N}$ addition rates ( $\leqslant 8 \mathrm{~kg} \mathrm{~N} \mathrm{ha}^{-1} \mathrm{yr}^{-1}$ ) of McHugh et al. (2017) were very low compared with our experiment (25 kg N ha ${ }^{-1} \mathrm{yr}^{-1}$ ) and that of Morrison et al. (2016) $\left(\geqslant 50 \mathrm{~kg} \mathrm{~N} \mathrm{ha}^{-1} \mathrm{yr}^{-1}\right)$.

Nevertheless, water addition had no significant effects on fungal abundance, in support of first hypothesis. The response could be resulted from the fact that water is not a limiting factor in our study, as speculated by Hawkes et al. (2011) that fungal responses to precipitation may be depending on the relative availability of water for metabolism, so that fungi only responded positively to rainfall in drier soils where water is limited. Similarly, fungal richness, Shannon and InvSimpson index did not respond to water input (Table 2), supporting our first hypothesis, but incompatible with the work of Hawkes et al. (2011) carried out in a grassland ecosystem, which can be ascribed to the difference in ecosystem types. Additionally, water addition also showed no impacts on fungal community composition (Table 3), confirming our first hypothesis, and supported Jumpponen and Jones (2014) that soil 
fungal communities are compositionally resilient to altered rainfall regime.

At phylum level, neither Ascomycota nor Basidiomycota significantly altered their relative abundance under $\mathrm{N}$ addition as indicated by the meta-analysis of Wang et al. (2018b), but in our study, the relative abundance of Ascomycota was marginally increased by $\mathrm{N}$ addition (Fig. 3), which was in accordance with the study of She et al. (2018) carried out in a desert shrubland. This could be explained by the copiotrophicoligotrophic theory originated from bacteria, now applied to fungi (Ho et al., 2017; Yao et al., 2017). Bacteria or fungi can be ecologically classified into copiotrophic and oligotrophic taxa. Copiotrophic taxa prefer labile soil organic $\mathrm{C}$ pools and flourish in habitats with high resource availability, in contrast, oligotrophic taxa are likely to outcompete copiotrophs and dominate in nutrient-poor environment due to their higher substrate affinities (Fierer et al., 2007). Ascomycota could roughly be classified into copiotrophic group (Ho et al., 2017; Yao et al., 2017), so the increase in its relative abundance under $\mathrm{N}$ addition was not surprising. In addition, it was reported that the relative abundance of oligotrophic Basidiomycota decreased following $\mathrm{N}$ enrichment (Entwistle et al., 2013), yet, in our study, Basidiomycota relative abundance tended to decrease but not significant may have been masked by large variations within treatment (Fig. 3).

4.3 Response of different functional fungal groups to $\mathrm{N}$ and water addition

In this study, the richness of pathogenic fungi was significantly increased following $\mathrm{N}$ enrichment (Fig. 4A), in support of our second hypothesis, and consistent with previous reports that application of inorganic fertilizer can increase the proportion of potential pathogenic fungi and may bring negative impacts on forest health (Paungfoo-Lonhienne et al., 2015; Hu et al., 2017). The richness and abundance of saprotrophic fungi (Fig. 4A, B), as expected, also responded positively to $\mathrm{N}$ addition. The thriving of saprotrophic fungi following $\mathrm{N}$ addition demonstrated the increased importance of decomposer and could have profound effects on $\mathrm{N}$ and $\mathrm{C}$ dynamics. Moreover, significant or marginal $\mathrm{N}$-water interactions were detected on the richness of pathogenic fungi or saprotrophic fungi (Fig. 4A). The significant $\mathrm{N}$-water interactions were also observed on soil fungi by Zhang et al. (2018b). It is possible that water addition enhances $\mathrm{N}$ loss through leaching and runoff.

In addition, the abundance of pathogenic fungi marginally positively responded to water addition (Fig. 4B), confirming the study of Barnes et al. (2018) on root-associated fungi, because increased moisture could be beneficial to the growth, reproduction and dispersal of existing pathogenic fungi (Woods et al., 2005; La Porta et al., 2008).

4.4 Soil properties mediated the effects of $\mathrm{N}$ and water addition on soil fungal community

We found that there were significant or marginal positive correlations between fungal alpha diversity index and soil $\mathrm{NH}_{4}{ }^{+}$content or soil moisture (Table 4). We speculate that $\mathrm{N}$ addition increased fungal alpha diversity probably via raising soil $\mathrm{N}$ availability and releasing $\mathrm{N}$ limitation. Meanwhile, the study of $\mathrm{He}$ et al. (2017), conducted in a subtropical forest, also showed the positive relationship between soil moisture and the Shannon index of fungal communities, which can be explained by the fact that fungi preferentially live in large soil pores, which are filled at high moisture but become empty at low moisture, and fungal community responded rapidly to soil moisture fluctuation (Kaisermann et al., 2015). Simultaneously, fungal community composition dissimilarity was positively correlated with the disparity of soil factors as a whole (Table 5). Furthermore, marginal or significant positive correlations between soil moisture or soil $\mathrm{NH}_{4}{ }^{+}$content and the richness of saprotrophic fungi and pathogenic fungi were also recorded (Table 6), which are readily comprehensible, because high soil moisture and resource availability can be favorable to the growth and propagation of certain saprotrophic fungi and pathogens (Woods et al., 2005; La Porta et al., 2008; Richardson, 2009). Besides, mycorrhizal fungal richness showed close relationship with soil $\mathrm{NH}_{4}{ }^{+}$content and $\mathrm{N} / \mathrm{P}$ ratio (Table 6 ), we speculate that $\mathrm{N}$ input mitigated $\mathrm{N}$ limitation for mycorrhizal fungi and imbalanced the nutrient supply of the ecosystem, increasing the importance of available P (Vitousek et al., 2010). These results together supported our third hypothesis.

An experiment conducted in a boreal forest ecosystem found that both $\mathrm{N}$ addition and season had significant impacts on fungal alpha diversity indices (Chao1 and Shannon), and their interaction was also observed in influencing fungal Shannon diversity (Yan et al., 2017). In addition, fungal community composition, at the same $\mathrm{N}$ addition level, was significantly different between summer and autumn. Simultaneously, the response of soil fungal community to increased rainfall also can be affected by seasonality, for example, Hawkes et al. (2011) showed that fungal communities were more abundant, diverse, and consistent under drought conditions, but less abundant, less diverse, and more variable during wetter periods and under rainfall increment treatments. In the following study, we should take the frequency and duration of watering, and seasonal and inter-annual variations into account.

\section{Conclusion}

In the present study we investigated the effects of increased $\mathrm{N}$ deposition and rainfall on the soil fungal biodiversity and community composition in forest ecosystem in a more natural way. The results demonstrated that soil fungal community composition could be altered by $\mathrm{N}$ addition at OTU level but showed high resistance at phylum level; however, the relative abundances of certain fungal phyla can be changed, the copiotrophic fungi can benefit from nutrient enrichment, but the relative abundance of oligotrophic fungi would be decreased. On the other hand, water addition generally 
showed no remarkable effects on fungal biodiversity and community composition. The results also indicated that increased $\mathrm{N}$ deposition and rainfall contributed to the thriving of pathogenic fungi and saprotrophic fungi, which can bring series of influences on forest health and ecosystem functions, and research in these area should be strengthened. Further study should take plant community data, frequency and duration of watering, and seasonal and inter-annual variations into account to better understand the response of soil fungi to climate change in forest ecosystems.

\section{Acknowledgments}

We thank Zuojian Zhang for the help in soil sampling. We also thank Minghui Che for the assistance in analysis of soil properties. This study was supported by the National Natural Science Foundation of China (41877050; 31300446; 41401286).

\section{Conflict of intrerest}

The authors declare no conflict of interest.

\section{References}

Affokpon, A., Coyne, D.L., Lawouin, L., Tossou, C., Dossou Agbèdè, R., Coosemans, J., 2011. Effectiveness of native West African arbuscular mycorrhizal fungi in protecting vegetable crops against root-knot nematodes. Biology and Fertility of Soils 47, 207-217.

Aguilar-Trigueros, C.A., Hempel, S., Powell, J.R., Anderson, I.C., Rillig, M.C., 2015. Branching out, towards a trait-based understanding of fungal ecology. Fungal Biology Reviews 29, 34-41.

Altschul, S.F., Madden, T.L., Schäffer, A.A., Zhang, J., Zhang, Z., Miller, W., Lipman, D.J., 1997. Gapped BLAST and PSI-BLAST: a new generation of protein database search programs. Nucleic Acids Research 25, 3389-3402.

Anderson, M.J., 2010. A new method for non-parametric multivariate analysis of variance. Austral Ecology 26, 32-46.

Barnes, C.J., van der Gast, C.J., McNamara, N.P., Rowe, R., Bending, G.D., 2018. Extreme rainfall affects assembly of the rootassociated fungal community. New Phytologist 220, 1172-1184.

Brown, J.R., Blankinship, J.C., Niboyet, A., van Groenigen, K.J., Dijkstra, P., Roux, X.L., Leadley, P.W., Hungate, B.A., 2012. Effects of multiple global change treatments on soil $\mathrm{N}_{2} \mathrm{O}$ fluxes. Biogeochemistry 109, 85-100.

Butterbach-Bahl, K., Gasche, R., Breuer, L., Papen, H., 1997. Fluxes of $\mathrm{NO}$ and $\mathrm{N}_{2} \mathrm{O}$ from temperate forest soils, impact of forest type, $\mathrm{N}$ deposition and of liming on the $\mathrm{NO}$ and $\mathrm{N}_{2} \mathrm{O}$ emissions. Nutrient Cycling in Agroecosystems 48, 79-90.

Chen, B., Nayuki, K., Kuga, Y., Zhang, X., Wu, S., Ohtomo, R., 2018. Uptake and intraradical immobilization of cadmium by arbuscular mycorrhizal fungi as revealed by a stable isotope tracer and synchrotron radiation $\mu \mathrm{X}$-ray fluorescence analysis. Microbes and Environments 33, 257-263.

Chen, Y.L., Xu, Z.W., Veresoglou, S.D., Yang, G.W., Chen, B.D., 2017. Nitrogen deposition and precipitation induced phylogenetic clus- tering of arbuscular mycorrhizal fungal communities. Soil Biology \& Biochemistry 115, 233-242.

Dagenais, T.R.T., Keller, N.P., 2009. Pathogenesis of Aspergillus fumigatus in invasive Aspergillosis. Clinical Microbiology Reviews 22, 447-465.

Dean, R.B., Dixon, W.J., 1951. Simplified statistics for small numbers of observations. Analytical Chemistry 23, 636-638.

Edgar, R.C., 2010. Search and clustering orders of magnitude faster than BLAST. Bioinformatics (Oxford, England) 26, 2460-2461.

Entwistle, E.M., Zak, D.R., Edwards, I.P., 2013. Long-term experimental nitrogen deposition alters the composition of the active fungal community in the forest floor. Soil Science Society of America Journal 77, 1648-1658.

Fierer, N., Bradford, M.A., Jackson, R.B., 2007. Toward an ecological classification of soil bacteria. Ecology 88, 1354-1364.

Frey, S.D., Six, J., Elliott, E.T., 2003. Reciprocal transfer of carbon and nitrogen by decomposer fungi at the soil-litter interface. Soil Biology \& Biochemistry 35, 1001-1004.

Galloway, J.N., Dentener, F.J., Capone, D.G., Boyer, E.W., Howarth, R.W., Seitzinger, S.P., Asner, G.P., Cleveland, C.C., Green, P.A., Holland, E.A., Karl, D.M., Michaels, A.F., Porter, J.H., Townsend, A.R., Vörösmarty, C.J., 2004. Nitrogen cycles, past, present, and future. Biogeochemistry 70, 153-226.

Gilbert, G.S., Webb, C.O., 2007. Phylogenetic signal in plant pathogen-host range. Proceedings of the National Academy of Sciences of the United States of America 104, 4979-4983.

Hawkes, C.V., Kivlin, S.N., Rocca, J.D., Huguet, V., Thomsen, M.A., Suttle, K.B., 2011. Fungal community responses to precipitation. Global Change Biology 17, 1637-1645.

He, D., Shen, W., Eberwein, J., Zhao, Q., Ren, L., Wu, Q.L., 2017. Diversity and co-occurrence network of soil fungi are more responsive than those of bacteria to shifts in precipitation seasonality in a subtropical forest. Soil Biology \& Biochemistry 115, 499-510.

Ho, A., Di Lonardo, D.P., Bodelier, P.L.E., 2017. Revisiting life strategy concepts in environmental microbial ecology. FEMS Microbiology Ecology 93, fix006.

Hu, X., Liu, J., Wei, D., Zhu, P., Cui, X., Zhou, B., Chen, X., Jin, J., Liu, X., Wang, G., 2017. Effects of over 30-year of different fertilization regimes on fungal community compositions in the black soils of northeast China. Agriculture, Ecosystems \& Environment 248, 113-122.

Huang, Y.Y., Olbrecht, L., Yang, X.X., He, J.S., 2014. Effects of nutrient additions on the arbuscular mycorrhizal fungal colonization in the alpine meadow on the tibetan plateau. Universitatis Pekinensis Acta Scientiarum Naturalium (Beijing Da Xue Xue Bao. Zi Ran Ke Xue Ban) 50, 911-918.

IPCC, 2013. Climate Change 2013, The Physical Science Basis. Working group I contribution to the fifth assessment report of the Intergovernmental Panel on Climate Change. Cambridge: Cambridge University Press.

Jumpponen, A., Jones, K.L., 2014. Tallgrass prairie soil fungal communities are resilient to climate change. Fungal Ecology 10, 44-57.

Kaisermann, A., Maron, P.A., Beaumelle, L., Lata, J.C., 2015. Fungal communities are more sensitive indicators to non-extreme soil 
moisture variations than bacterial communities. Applied Soil Ecology 86, 158-164.

Keiblinger, K.M., Hall, E.K., Wanek, W., Szukics, U., Hämmerle, I., Ellersdorfer, G., Böck, S., Strauss, J., Sterflinger, K., Richter, A., Zechmeister-Boltenstern, S., 2010. The effect of resource quantity and resource stoichiometry on microbial carbon-use-efficiency. FEMS Microbiology Ecology 73, 430-440.

La Porta, N., Capretti, P., Thomsen, I.M., Kasanen, R., Hietala, A.M., Von Weissenberg, K., 2008. Forest pathogens with higher damage potential due to climate change in Europe. Canadian Journal of Plant Pathology 30, 177-195.

Ladau, J., Shi, Y., Jing, X., He, J.S., Chen, L., Lin, X., Fierer, N., Gilbert, J.A., Pollard, K.S., Chu, H., 2018. Existing climate change will lead to pronounced shifts in the diversity of soil prokaryotes. mSystems 3, e00167-e18.

Li, Y., Bezemer, T.M., Yang, J., Lü, X., Li, X., Liang, W., Han, X., Li, Q., 2018. Changes in litter quality induced by $N$ deposition alter soil microbial communities. Soil Biology \& Biochemistry 130, 33-42.

Liu, L., Wang, X., Lajeunesse, M.J., Miao, G., Piao, S., Wan, S., Wu, Y., Wang, Z., Yang, S., Li, P., Deng, M., 2016. A cross-biome synthesis of soil respiration and its determinants under simulated precipitation changes. Global Change Biology 22, 1394-1405.

Looby, C.I., Treseder, K.K., 2018. Shifts in soil fungi and extracellular enzyme activity with simulated climate change in a tropical montane cloud forest. Soil Biology \& Biochemistry 117, 87-96.

Loreau, M., de Mazancourt, C., 2013. Biodiversity and ecosystem stability: a synthesis of underlying mechanisms. Ecology Letters 16, 106-115.

Lu, X., Mao, Q., Gilliam, F.S., Luo, Y., Mo, J., 2014. Nitrogen deposition contributes to soil acidification in tropical ecosystems. Global Change Biology 20, 3790-3801.

Magoč, T., Salzberg, S.L., 2011. FLASH: fast length adjustment of short reads to improve genome assemblies. Bioinformatics (Oxford, England) 27, 2957-2963.

McGuire, K.L., Fierer, N., Bateman, C., Treseder, K.K., Turner, B.L., 2012. Fungal community composition in neotropical rain forests: the influence of tree diversity and precipitation. Microbial Ecology 63, 804-812.

McHugh, T.A., Morrissey, E.M., Mueller, R.C., Gallegos-Graves, V., Kuske, C.R., Reed, S.C., 2017. Bacterial, fungal, and plant communities exhibit no biomass or compositional response to two years of simulated nitrogen deposition in a semiarid grassland. Environmental Microbiology 19, 1600-1611.

Meier, C.L., Rapp, J., Bowers, R.M., Silman, M., Fierer, N., 2010. Fungal growth on a common wood substrate across a tropical elevation gradient: temperature sensitivity, community composition, and potential for above-ground decomposition. Soil Biology \& Biochemistry 42, 1083-1090.

Morrison, E.W., Frey, S.D., Sadowsky, J.J., Van Diepen, L.T.A., Thomas, W.K., Pringle, A., 2016. Chronic nitrogen additions fundamentally restructure the soil fungal community in a temperate forest. Fungal Ecology 23, 48-57.

Nguyen, N.H., Song, Z.W., Bates, S.T., Branco, S., Tedersoo, L., Menke, J., Schilling, J.S., Kennedy, P.G., 2016. FUNGuild, an open annotation tool for parsing fungal community datasets by ecological guild. Fungal Ecology 20, 241-248.
Ni, X., Liao, S., Wu, F., Groffman, P.M., 2019. Short-term precipitation pulses stimulate soil $\mathrm{CO}_{2}$ emission but do not alter $\mathrm{CH}_{4}$ and $\mathrm{N}_{2} \mathrm{O}$ fluxes in a northern hardwood forest. Soil Biology \& Biochemistry 130, 8-11.

Nilsson, R.H., Larsson, K.H., Taylor, A.F.S., Bengtsson-Palme, J., Jeppesen, T.S., Schigel, D., Kennedy, P., Picard, K., Glõckner, F. O., Tedersoo, L., Saar, I., Kõljalg, U., Abarenkov, K., 2019. The UNITE database for molecular identification of fungi: handling dark taxa and parallel taxonomic classifications. Nucleic Acids Research 47, D259-D264.

Oksanen, J., Blanchet, F.G., Kindt, R., Legendre, P., O'Hara, R.B., Simpson, G.L., Solymos, P., Stevens, M.H.H., Wagner, H., 2013. Vegan: Community Ecology Package. R package version2.0-10.

Olsen, S.R., Cole, C.V., Watanabe, F.S., Dean, L.A., 1954. Estimation of available phosphorus in soils by extraction with sodium bicarbonate. USDA Circular 939, 1-19.

Paungfoo-Lonhienne, C., Yeoh, Y.K., Kasinadhuni, N.R.P., Lonhienne, T.G.A., Robinson, N., Hugenholtz, P., Ragan, M.A., Schmidt, S., 2015. Nitrogen fertilizer dose alters fungal communities in sugarcane soil and rhizosphere. Scientific Reports 5, 8678.

Rajala, T., Peltoniemi, M., Pennanen, T., Mäkipää, R., 2012. Fungal community dynamics in relation to substrate quality of decaying Norway spruce ( Picea abies [L.] Karst.) logs in boreal forests. FEMS Microbiology Ecology 81, 494-505.

Richardson, M., 2009. The ecology of the Zygomycetes and its impact on environmental exposure. Clinical Microbiology and Infection 15, 2-9.

Rosier, C.L., Levia, D.F., Van Stan, J.T., Aufdenkampe, A., Kan, J., 2016. Seasonal dynamics of the soil microbial community structure within the proximal area of tree boles: possible influence of stemflow. European Journal of Soil Biology 73, 108-118.

Rosier, C.L., Moore, L.D., Wu, T.H., Van Stan, J.T., 2015a. Forest canopy precipitation partitioning: an important plant trait influencing the spatial structure of the symbiotic soil microbial community. Advances in Botanical Research 75, 215-240.

Rosier, C.L., Van Stan, J.T. II, Moore, D.M., Schrom, J.O.S., Wu, T.H., Reichard, J.S., Kan, J.J., 2015b. Forest canopy structural controls over throughfall affect soil microbial community structure in an epiphyte-laden maritime oak stand. Ecohydrology 8, 1459-1470.

Rousk, J., Brookes, P.C., Bååth, E., 2010. The microbial PLFA composition as affected by $\mathrm{pH}$ in an arable soil. Soil Biology \& Biochemistry 42, 516-520.

She, W., Bai, Y., Zhang, Y., Qin, S., Feng, W., Sun, Y., Zheng, J., Wu, B., 2018. Resource availability drives responses of soil microbial communities to short-term precipitation and nitrogen addition in a desert shrubland. Frontiers in Microbiology 9, 186.

Shi, L., Zhang, H., Liu, T., Mao, P., Zhang, W., Shao, Y., Fu, S., 2018. An increase in precipitation exacerbates negative effects of nitrogen deposition on soil cations and soil microbial communities in a temperate forest. Environmental Pollution 235, 293-301.

Smith, S.E., Read, D.J., 2008. Mycorrhizal symbiosis. London: Academic press

Thorn, G., 1997. The fungi in soil. In: Dirk Van Elsas J, Trevors JT, Wellington EMH, eds. Modern Soil Microbiology. New York: Marcel Dekker Inc, 63-127.

Tian, D., Du, E., Jiang, L., Ma, S., Zeng, W., Zou, A., Feng, C., Xu, L., 
Xing, A., Wang, W., Zheng, C., Ji, C., Shen, H., Fang, J., 2018. Responses of forest ecosystems to increasing $\mathrm{N}$ deposition in China: A critical review. Environmental Pollution 243, 75-86.

Tian, D., Niu, S., 2015. A global analysis of soil acidification caused by nitrogen addition. Environmental Research Letters 10, 024019.

Vitousek, P.M., Porder, S., Houlton, B.Z., Chadwick, O.A., 2010. Terrestrial phosphorus limitation: mechanisms, implications, and nitrogen-phosphorus interactions. Ecological Applications 20, 515.

Walkley, A., 1947. A critical examination of a rapid method for determining organic carbon in soils-effect of variations in digestion conditions and of inorganic soil constituents. Soil Science 63, 251264.

Wang, C., Liu, D., Bai, E., 2018b. Decreasing soil microbial diversity is associated with decreasing microbial biomass under nitrogen addition. Soil Biology \& Biochemistry 120, 126-133.

Wang, Y., Ji, H., Hu, Y., Wang, R., Rui, J., Guo, S., 2018a. Different selectivity in fungal communities between manure and mineral fertilizers, a study in an alkaline soil after 30 years fertilization. Frontiers in Microbiology 9, 2613.

Woods, A., Coates, K.D., Hamann, A. 2005. Is an unprecedented dothistroma needle blight epidemic related to climate change? BioScience 55, 761-769.

Wu, S., Hu, Y., Zhang, X., Sun, Y., Wu, Z., Li, T., Lv, J., Li, J., Zhang, J., Zheng, L., Huang, L., Chen, B., 2018. Chromium detoxification in arbuscular mycorrhizal symbiosis mediated by sulfur uptake and metabolism. Environmental and Experimental Botany 147, 43-52.

Yan, G., Xing, Y., Xu, L., Wang, J., Dong, X., Shan, W., Guo, L., Wang, Q., 2017. Effects of different nitrogen additions on soil microbial communities in different seasons in a boreal forest. Ecosphere 8, e01879.

Yao, F., Yang, S., Wang, Z., Wang, X., Ye, J., Wang, X., DeBruyn, J.M., Feng, X., Jiang, Y., Li, H., 2017. Microbial taxa distribution is associated with ecological trophic cascades along an elevation gradient. Frontiers in Microbiology 8, 2071.

Zhang, H., Liu, H., Zhao, J., Li, G., Lai, X., Li, J., Wang, H., Yang, D.L., 2018b. Response of soil fungal community structure to nitrogen and water addition in Stipa baicalensis steppe. Acta Ecologica Sinica (Sheng Tai Xue Bao) 38, 195-205.

Zhang, H., Wang, L., Liu, H., Zhao, J., Li, G., Wang, H., Lai, X., Li, J., Xiu, W., Yang, D., 2018a. Nitrogen deposition combined with elevated precipitation is conducive to maintaining the stability of the soil fungal diversity on the Stipa baicalensis steppe. Soil Biology \& Biochemistry 117, 135-138.

Zhang, W., Shen, W., Zhu, S., Wan, S., Luo, Y., Yan, J., Wang, K., Liu, L., Dai, H., Li, P., Dai, K., Zhang, W., Liu, Z., Wang, F., Kuang, Y., Li, Z., Lin, Y., Rao, X., Li, J., Zou, B., Cai, X., Mo, J., Zhao, P., Ye, Q., Huang, J., Fu, S., 2015. Can canopy addition of nitrogen better illustrate the effect of atmospheric nitrogen deposition on forest ecosystem? Scientific Reports 5, 11245.

Zhao, A., Liu, L., Xu, T., Shi, L., Xie, W., Zhang, W., Fu, S., Feng, H., Chen, B., 2018. Influences of canopy nitrogen and water addition on AM fungal biodiversity and community composition in a mixed deciduous forest of China. Frontiers in Plant Science 9, 1842.

Zhou, J., Jiang, X., Zhou, B., Zhao, B., Ma, M., Guan, D., Li, J., Chen, S., Cao, F., Shen, D., Qin, J., 2016. Thirty four years of nitrogen fertilization decreases fungal diversity and alters fungal community composition in black soil in northeast China. Soil Biology \& Biochemistry 95, 135-143 